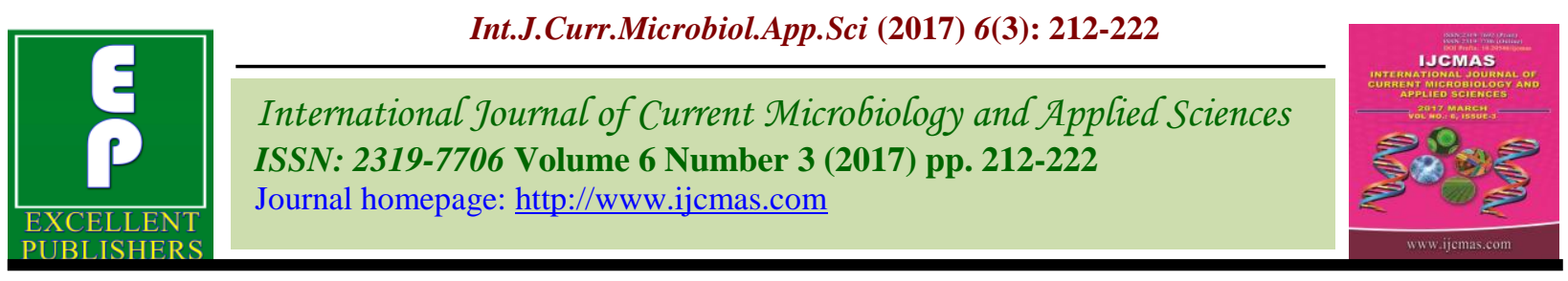

Original Research Article

https://doi.org/10.20546/ijcmas.2017.603.022

\title{
Agrometeorological Indices and Phenology of Basmati Rice (Oryza sativa L.) under Different Dates of Transplanting
}

\author{
Abhilash*, Chander Shekhar Dagar, Raj Singh, Premdeep and Raman Sharma \\ Department of Agricultural Meteorology, College of Agriculture (COA), CCS Haryana \\ Agricultural University, Hisar-125004, Haryana, India \\ *Corresponding author
}

\section{A B S T R A C T}

\section{Keywords}

Basmati rice,

Agromet indices,

Radiation

interception,

Phonological stages.

Article Info

Accepted:

08 February 2017

Available Online:

10 March 2017
A field experiment was conducted during Kharif season of 2015 at Chaudhary Charan Singh Haryana Agricultural University, Rice Research Station, Kaul, India to study the phenology, and various agrometeorological indices viz., accumulated growing degree days (GDD), helio thermal units (HTU), photo thermal units (PTU), radiation use efficiency (RUE) and heat use efficiency (HUE) of basmati rice cultivars grown under different dates of transplanting. The rice varieties CSR 30, HB 2, PB 1121 and PB 1509 were transplanted on three dates viz., $25^{\text {th }}$ June, $10^{\text {th }}$ July and $25^{\text {th }}$ July. Heat units required to attain different phenological stages decreased in all the varieties with every delay in transplanting date. The crop transplanted on $25^{\text {th }}$ June took maximum calendar days, growing degree days, helio thermal units and photo thermal units, to attain different phenological stages till physiological maturity which reduced significantly with subsequent delay in transplanting date. Also, Radiation and heat use efficiency was found to be highest in crop transplanted on $25^{\text {th }}$ June followed by $10^{\text {th }}$ July and $25^{\text {th }}$ July. Among varieties, CSR 30 consumed highest GDD, HTU and PTU as compared to other varieties. The RUE and HUE for grain production was highest in HB 2 at the time of harvest.

\section{Introduction}

Rice (Oryza sativa L.) is among one of the most important cereal crops grown under different hydrological conditions in Asia. About $90 \%$ production and consumption of world's rice occurs in Asia (FAOSTAT, 2014). In India, it is dominating staple food crop of fertile alluvial soils of North-West regions of the country, particularly IndoGangetic Plains (Walia and Walia, 2007). Rice contributing around $45 \%$ of the total food grain production and being the staple food for more than two third of the population, plays the key role to sustain food sufficiency in the country (Rai and Kushwaha,
2005). India holds second position in production of rice in the world with production of 105.48 million tonnes from 43.90 million hectares, with a productivity of $2390 \mathrm{~kg} / \mathrm{ha}$ during 2015 (Economic survey, 2015-16). Rice production is affected by various meteorological variables like rainfall, temperature etc (Ji et al., 2007). The extreme climatic conditions, particularly high temperature, reduce the plant growth and yield significantly (Satake and Yoshida, 1978). The crop growth response is mainly influenced by the microclimate of crop canopy. Microclimatic environment in the 
crop refers to the physical conditions from the canopy top to the soil (up to maximum rooting zone) which affects development and yield of crop. Various environmental factors influencing crop growth are air and leaf temperatures, interception of photosynthetically active radiation, prevailing wind speed, soil moisture availability, relative humidity and concentration of $\mathrm{CO}_{2}$. Temperature and light radiation are key factors affecting crop production. During crop growth period, the occurrence of various phenological events can be estimated by computing accumulated growing degree days (Gouri et. al., 2005). Accumulated growing degree days (GDD) provides an estimate of harvest date as well as development stages of crop (Ketring and Wheless, 1989). Various developmental stages as well as harvest date of crop can be estimated from the knowledge of accumulated GDD. Thermal time can be used as a tool for characterizing thermal responses in different crops as it is an independent variable to describe plant development (Dwyer and Stewart, 1986). Heat use efficiency (HUE), i.e., efficiency of heat utilization in terms of dry matter accumulation, depends on genetic factors, crop type and sowing time and has great practical application (Rao et al., 1999). Crop phenology is an essential component of weather based dynamic crop growth and yield simulation models and can be used to estimate the most appropriate date and time of specific development process. The duration of each phenophase determines the dry matter accumulation and its partitioning into different organs (Dalton, 1967; Wang, 1960) reported that the duration of growth stage of any particular species was directly related to temperature and it could be predicted using the sum of daily air temperature. Temperature is an important environmental factor that influences the growth and development, phenology and yield of crop (Bishnoi et al., 1995). Hence, it becomes imperative to have the knowledge of exact duration of various phenological stages of crop in a particular growing environment and their impact on its yield. In the present study, an attempt is made to predict the growth and yield of Basmati rice with agroclimatic indices viz. growing degree days, helio thermal units, photo thermal units, heat use efficiency and radiation use efficiency.

\section{Materials and Methods}

The field experiment was conducted at the research farm of Chaudhary Charan Singh Haryana Agricultural University, Rice Research Station, Kaul (Kaithal), Haryana, India. It is situated at $29^{\circ} 51^{\prime} \mathrm{N}$ latitude and $76^{\circ} 39^{\prime}$ E longitude with an elevation of 230.7 meters above the mean sea level. The station lies in the eastern agroclimatic zone of Haryana. The experiment included three dates of transplanting viz. $25^{\text {th }}$ June, $10^{\text {th }}$ July and $25^{\text {th }}$ July as main plot treatments and four cultivars namely CSR 30, Pusa Basmati 1121, Pusa Basmati 1509 and Haryana Basmati 2 as subplot treatments, resulting in 12 treatment combinations. The experiment was laid out in a split-plot design with four replications. Four plants were randomly selected from each plot and pulled out every time periodically, at 20 days interval starting from 30 DAT till harvest of crop, for recording plant dry matter and then their average weight was taken. The agroclimatic indices namely growing degree days, helio thermal units, photo thermal units, radiation use efficiency and heat use efficiency were worked out.

\section{Phenological observations}

The crop was inspected at frequent intervals ( 2 or 3 days) to observe the phenological events closely. The phenological events recorded were tillering, booting, heading, anthesis, milking, dough and Physiological maturity. 


\section{Growing degree days (GDD)}

Cumulative growing degree days were determined by summing the daily mean temperature above base temperature, expressed in degree day. For Oryza species, $\mathrm{T}_{\text {base }}$ is considered $10 \mathrm{C}$ (Ghadekar, 2001). This was determined by using the following formula as per (Nuttonson, 1995):

$$
\mathrm{GDD}=\frac{\left(\mathrm{T}_{\max }+\mathrm{T}_{\min }\right)}{2}-\mathrm{T}_{\text {base } \ldots . .(\mathrm{i})}
$$

Where,

$\mathrm{T}_{\max }=$ Daily maximum temperature $\left({ }^{\circ} \mathrm{C}\right)$

$\mathrm{T}_{\min }=$ Daily minimum temperature $\left({ }^{\circ} \mathrm{C}\right)$

$\mathrm{T}_{\text {base }}=$ Minimum threshold $/$ base temperature ( $\mathrm{C})$

\section{Heliothermal units (HTU), degree day hrs}

The heliothermal units for a day represent the product of GDD and the hours of bright sunshine for that day. The sum of HTU for particular phenophases of interest was determined according to the equation:

$\mathrm{HTU}=\sum\{\mathrm{GDD} \times \mathrm{BSS}(\mathrm{n})\}$

Where,

GDD $=$ growing degree days

BSS (n) = bright sun shine hours (hrs)

\section{Photothermal units (PTU), degree day hrs}

Photothermal units are the cumulative value of growing degree days, multiplied by the day length. This can be mathematically represented using the following formula:

$\mathrm{PTU}=\sum(\mathrm{GDD} * \mathrm{~N}) \ldots \ldots(\mathrm{iii})$

Where,

GDD $=$ Growing degree days

$\mathrm{N}$ = Maximum possible sunshine hours or day length (hrs)

\section{Radiation use efficiency (RUE), $\mathrm{g} \mathrm{MJ}^{-1}$}

The radiation use efficiency is defined as the amount of dry matter produced per unit of intercepted photosynthetically active radiation (PAR). RUE of basmati rice at 20 days interval was computed by using the following formula:

$\operatorname{RUE}(\mathrm{g} / \mathrm{MJ})=$

Biomass production $\left(\mathrm{g} / \mathrm{m}^{2}\right)$

during 20 days interval

Cumulative iPAR $\left(\mathrm{MJ} / \mathrm{m}^{2}\right)$

during 20 days interval

Heat use efficiency (HUE), $\mathrm{g} \mathrm{ha}^{-1}{ }^{\circ} \mathrm{C}_{\mathrm{day}^{-1}}$

Heat use efficiency is also represented by thermal time use efficiency (TTUE), which indicates the amount of dry matter produced per unit of growing degree days or thermal time. This was computed by using the following formula:

$\operatorname{HUE}\left(\mathrm{g} / \mathrm{m}^{2^{\circ}} \mathrm{C}\right.$ day $)=$

Biomass production $\left(\mathrm{g} / \mathrm{m}^{2}\right)$

during 20 days interval

Growing degree days ( $\mathrm{C}$ day)

during 20 days interval

\section{Results and Discussion}

\section{Phenology}

Among the different dates of transplanting, rice transplanted on $25^{\text {th }}$ June takes higher number of days to attain physiological maturity followed by $10^{\text {th }}$ July and $25^{\text {th }}$ July during the kharif 2015 crop season (Table 1). These results confirmed the findings of Majos and Pava (1980). Sharma et al., (2011) also reported that the early transplanting took more number of days for maturity as 
compared to late transplanting. Among the four cultivars PB 1509 was chosen from the short-duration group (110-120 days from seed to seed), whereas PB 1121 and HB 2 belongs to the medium-duration group (135145 days) and CSR 30 belongs to longduration group (145-150 days). Hence, CSR 30 took maximum number of days to attain physiological maturity followed by HB 2, PB 1121 and PB 1509.

\section{Growing Degree Days (GDD)}

Growing degree days accumulated at different phenophases were calculated during crop season. The highest number of growing degree days were accumulated by $25^{\text {th }}$ June transplanted crop followed by $10^{\text {th }}$ July and $25^{\text {th }}$ July transplanted crops at all the phenophases. Among the varieties, the maximum growing degree days were accumulated in variety CSR 30 followed by variety HB 2, PB 1121 and PB 1509 to reach physiological maturity during the crop season. Decrease in heat units with delay in transplanting has also been reported by Singh and Pal (2003) and Rajput et al., (1987).

In general, $25^{\text {th }}$ June transplanted crop accumulated higher degree days and with each delay in transplanting the degree day accumulation decreased during the crop seasons. For different transplanting dates, AGDD to reach physiological maturity ranged from 1791.0 to 2342.9 degree days, 1802.2 to 2133.9 degree days, 1802.2 to 2118.7 degree days and 1575.3 to 1903.6 degree days for varieties CSR 30, HB 2, PB 1121 and PB 1509, respectively (Table 2). Similar results were also obtained by Sharma et al., (2011) reporting that accumulated growing degree days was higher under early transplanted crop.

Table.1 Effect of transplanting time on phenophases of Basmati rice varieties

\begin{tabular}{|c|c|c|c|c|c|c|c|}
\hline \multirow{2}{*}{ Treatments } & \multicolumn{7}{|c|}{ Days after transplanting (DAT) } \\
\hline & Tillering & Booting & Heading & Anthesis & Milking & Dough & $\mathbf{P M}$ \\
\hline \multicolumn{8}{|c|}{ Transplanting dates } \\
\hline $25^{\text {th }}$ June & 33.2 & 56.8 & 75.6 & 81.6 & 97.0 & 105.6 & 115.33 \\
\hline $10^{\text {th }}$ July & 32.4 & 52.8 & 67.1 & 72.7 & 86.3 & 97.1 & 107.16 \\
\hline $25^{\text {th }}$ July & 32.1 & 49.0 & 62.0 & 67.6 & 80.2 & 89.4 & 98.95 \\
\hline CD at $5 \%$ & 0.38 & 0.53 & 0.58 & 0.46 & 0.46 & 0.63 & 0.59 \\
\hline \multicolumn{8}{|c|}{ Varieties } \\
\hline CSR-30 & 38.9 & 60.8 & 76.9 & 82.5 & 97.8 & 107.5 & 117.5 \\
\hline PB-1121 & 32.0 & 54.0 & 70.3 & 76.5 & 90.2 & 99.9 & 108.9 \\
\hline PB-1509 & 27.2 & 42.7 & 55.0 & 60.2 & 72.8 & 81.8 & 92.5 \\
\hline HB-2 & 32.3 & 54.0 & 70.6 & 76.7 & 90.5 & 100.3 & 109.7 \\
\hline CD at $5 \%$ & 0.69 & 0.42 & 0.73 & 0.68 & 0.68 & 0.67 & 0.50 \\
\hline
\end{tabular}


Table.2 Growing degree days (GDD) requirement of Basmati rice varieties at various phenophases under different transplanting time, degree days

\begin{tabular}{|c|c|c|c|c|c|c|c|c|c|c|c|c|}
\hline \multirow{2}{*}{$\begin{array}{c}\text { Phenological } \\
\text { stages }\end{array}$} & \multicolumn{4}{|c|}{$25^{\text {th }}$ June } & \multicolumn{4}{|c|}{$10^{\text {th }}$ July } & \multicolumn{4}{|c|}{$25^{\text {th }}$ July } \\
\hline & $\begin{array}{c}\text { CSR- } \\
30\end{array}$ & $\begin{array}{l}\text { PB- } \\
1121\end{array}$ & $\begin{array}{l}\text { PB- } \\
1509\end{array}$ & HB-2 & $\begin{array}{c}\text { CSR- } \\
30\end{array}$ & $\begin{array}{l}\text { PB- } \\
1121\end{array}$ & $\begin{array}{l}\text { PB- } \\
1509\end{array}$ & HB-2 & $\begin{array}{c}\text { CSR- } \\
30\end{array}$ & $\begin{array}{l}\text { PB- } \\
1121\end{array}$ & $\begin{array}{l}\text { PB- } \\
1509\end{array}$ & HB-2 \\
\hline Tillering & 762.4 & 629.0 & 528.5 & 629.3 & 744.5 & 609.0 & 518.9 & 609.0 & 728.3 & 608.0 & 514.2 & 608.0 \\
\hline Booting & 1336.7 & 1064.5 & 858.5 & 1064.5 & 1165.1 & 1034.7 & 801.0 & 1034.7 & 969.3 & 989.3 & 786.3 & 989.3 \\
\hline Heading & 1690.9 & 1430.7 & 1178.7 & 1430.7 & 1423.4 & 1333.6 & 1015.1 & 1333.6 & 1237.5 & 1237.5 & 950.5 & 1221.8 \\
\hline Anthesis & 1792.8 & 1558.1 & 1277.1 & 1558.1 & 1540.3 & 1441.4 & 1110.7 & 1423.4 & 1331.4 & 1314.8 & 1046.8 & 1348.4 \\
\hline Milking & 2118.7 & 1810.6 & 1521.4 & 1826.3 & 1769.8 & 1651.8 & 1352.6 & 1651.8 & 1515.0 & 1545.1 & 1253.5 & 1560.3 \\
\hline Dough & 2222.7 & 1953.8 & 1706.7 & 1970.5 & 1948.0 & 1831.9 & 1508.6 & 1831.9 & 1661.2 & 1674.4 & 1398.1 & 1687.4 \\
\hline $\begin{array}{c}\text { Physiological } \\
\text { Maturity }\end{array}$ & 2342.9 & 2118.7 & 1903.6 & 2133.9 & 2089.0 & 1974.2 & 1701.1 & 1986.2 & 1791.0 & 1802.2 & 1575.3 & 1802.2 \\
\hline
\end{tabular}


Table.3 Helio thermal units (HTU) requirement of Basmati rice varieties at various phenophases under different transplanting time, degree day hours

\begin{tabular}{|c|c|c|c|c|c|c|c|c|c|c|c|c|}
\hline \multirow{2}{*}{$\begin{array}{c}\text { Phenological } \\
\text { stages }\end{array}$} & \multicolumn{4}{|c|}{$25^{\text {th }}$ June } & \multicolumn{4}{|c|}{$10^{\text {th }}$ July } & \multicolumn{4}{|c|}{$25^{\text {th }}$ July } \\
\hline & CSR-30 & PB-1121 & PB-1509 & HB-2 & CSR-30 & PB-1121 & PB-1509 & HB-2 & CSR-30 & PB-1121 & PB-1509 & HB-2 \\
\hline Tillering & 5079.39 & 3769.61 & 3236.33 & 3788.31 & 4898.56 & 3636.36 & 3135.63 & 3636.36 & 3686.54 & 3291.98 & 2973.82 & 3291.98 \\
\hline Booting & 8686.28 & 7598.47 & 5600.57 & 7598.47 & 7665.96 & 6365.27 & 5460.15 & 6365.27 & 7412.47 & 6180.83 & 4222.42 & 6180.83 \\
\hline Heading & 11745.73 & 9587.12 & 7219.34 & 9587.12 & 9586.49 & 9175.40 & 6999.69 & 9152.22 & 9175.40 & 9152.22 & 6147.16 & 9030.50 \\
\hline Anthesis & 12415.51 & 10982.08 & 8038.82 & 10982.08 & 10598.40 & 10012.50 & 7903.62 & 10356.88 & 10183.48 & 9672.89 & 7075.31 & 9586.49 \\
\hline Milking & 15485.10 & 12600.11 & 10590.26 & 12745.01 & 12871.95 & 12026.81 & 9357.42 & 12132.86 & 11779.90 & 11766.50 & 9349.80 & 11766.50 \\
\hline Dough & 16268.28 & 14087.51 & 11772.50 & 14249.99 & 14201.92 & 13275.41 & 10837.34 & 13275.41 & 12953.32 & 13065.95 & 10279.10 & 13180.35 \\
\hline $\begin{array}{c}\text { Physiological } \\
\text { Maturity }\end{array}$ & 17193.09 & 15485.10 & 13582.11 & 15596.42 & 15054.04 & 14520.60 & 12343.34 & 14604.60 & 13659.93 & 13750.24 & 12266.81 & 13750.24 \\
\hline
\end{tabular}


Table.4 Photo thermal units (PTU) requirement of Basmati rice varieties at various phenophases under different transplanting time, degree day hours

\begin{tabular}{|c|c|c|c|c|c|c|c|c|c|c|c|c|}
\hline \multirow{2}{*}{$\begin{array}{c}\text { Phenological } \\
\text { stages }\end{array}$} & \multicolumn{4}{|c|}{$25^{\text {th }}$ June } & \multicolumn{4}{|c|}{$10^{\text {th }}$ July } & \multicolumn{4}{|c|}{$25^{\text {th }}$ July } \\
\hline & CSR-30 & PB-1121 & PB-1509 & HB-2 & CSR-30 & PB-1121 & PB-1509 & HB-2 & CSR-30 & PB-1121 & PB-1509 & HB-2 \\
\hline Tillering & 9856.57 & 7854.03 & 6796.02 & 8119.45 & 9451.72 & 7707.59 & 6558.70 & 7707.59 & 9054.73 & 7565.12 & 6371.13 & 7565.12 \\
\hline Booting & 17152.65 & 13737.25 & 11100.74 & 13737.25 & 14703.07 & 13096.42 & 10168.93 & 13096.42 & 12014.77 & 12257.29 & 9773.99 & 12257.29 \\
\hline Heading & 21471.07 & 18313.29 & 15179.25 & 18313.29 & 17827.39 & 16749.81 & 12852.53 & 16749.81 & 15227.32 & 15227.32 & 11786.99 & 15041.24 \\
\hline Anthesis & 22685.18 & 19868.80 & 16411.63 & 19868.80 & 19213.79 & 18042.05 & 14035.61 & 17827.39 & 16328.79 & 16134.87 & 12952.01 & 16527.02 \\
\hline Milking & 26474.20 & 22895.28 & 19423.17 & 23081.35 & 21881.08 & 20518.02 & 16978.51 & 20518.02 & 18449.92 & 18794.10 & 15415.99 & 18966.58 \\
\hline Dough & 27654.77 & 24574.25 & 21659.60 & 24768.84 & 23905.23 & 22591.90 & 18839.04 & 22591.90 & 20107.43 & 20256.17 & 17104.39 & 20401.86 \\
\hline $\begin{array}{c}\text { Physiological } \\
\text { Maturity }\end{array}$ & 28998.35 & 26474.20 & 23988.90 & 26648.13 & 25473.77 & 24199.66 & 21090.27 & 24333.91 & 21553.02 & 21675.97 & 19137.05 & 21675.97 \\
\hline
\end{tabular}


Table.5 Heat use efficiency (HUE) of Basmati rice varieties at various growth intervals under different transplanting time, $\mathrm{g} \mathrm{ha}^{-1}{ }^{\circ} \mathrm{C}^{-1}$ day $^{-1}$

\begin{tabular}{|c|c|c|c|c|c|c|c|c|c|c|c|c|}
\hline $\begin{array}{c}\text { Phenological } \\
\text { stages }\end{array}$ & \multicolumn{4}{|c|}{$\mathbf{2 5}^{\text {th }}$ June } & \multicolumn{4}{|c|}{$1^{\text {th }}$ July } & \multicolumn{4}{c|}{$\mathbf{2 5}^{\text {th }}$ July } \\
\hline & $\begin{array}{c}\text { CSR- } \\
\mathbf{3 0}\end{array}$ & $\begin{array}{c}\text { PB- } \\
\mathbf{1 1 2 1}\end{array}$ & $\begin{array}{c}\text { PB- } \\
\mathbf{1 5 0 9}\end{array}$ & $\begin{array}{c}\text { HB- } \\
\mathbf{2}\end{array}$ & $\begin{array}{c}\text { CSR- } \\
\mathbf{3 0}\end{array}$ & $\begin{array}{c}\text { PB- } \\
\mathbf{1 1 2 1}\end{array}$ & $\begin{array}{c}\text { PB- } \\
\mathbf{1 5 0 9}\end{array}$ & $\begin{array}{c}\text { HB- } \\
\mathbf{2}\end{array}$ & $\begin{array}{c}\text { CSR- } \\
\mathbf{3 0}\end{array}$ & $\begin{array}{c}\text { PB- } \\
\mathbf{1 1 2 1}\end{array}$ & $\begin{array}{c}\text { PB- } \\
\mathbf{1 5 0 9}\end{array}$ & $\begin{array}{c}\text { HB- } \\
\mathbf{2}\end{array}$ \\
\hline 30 DAT & 0.11 & 0.11 & 0.10 & 0.11 & 0.11 & 0.09 & 0.10 & 0.10 & 0.11 & 0.09 & 0.10 & 0.10 \\
\hline $\mathbf{5 0}$ DAT & 0.34 & 0.24 & 0.28 & 0.25 & 0.33 & 0.23 & 0.27 & 0.24 & 0.30 & 0.21 & 0.25 & 0.22 \\
\hline 70 DAT & 0.93 & 0.73 & 1.03 & 0.73 & 0.85 & 0.66 & 0.93 & 0.66 & 0.85 & 0.66 & 0.93 & 0.66 \\
\hline 90 DAT & 1.03 & 0.83 & 0.83 & 0.84 & 1.00 & 0.81 & 0.81 & 0.82 & 0.96 & 0.78 & 0.78 & 0.79 \\
\hline At Harvest & 0.76 & 0.79 & 0.34 & 0.86 & 0.74 & 0.78 & 0.33 & 0.85 & 0.68 & 0.71 & 0.30 & 0.77 \\
\hline
\end{tabular}

Table.6 Effect of transplanting time on radiation use efficiency (RUE) of Basmati rice varieties at various growth intervals, $\mathrm{g} \mathrm{MJ}^{-1}$

\begin{tabular}{|c|c|c|c|c|c|c|c|c|c|c|c|c|}
\hline $\begin{array}{c}\text { Phenological } \\
\text { stages }\end{array}$ & \multicolumn{4}{|c|}{$\mathbf{2 5}^{\text {th }}$ June } & \multicolumn{4}{c|}{$\mathbf{1 0}^{\text {th }}$ July } & \multicolumn{4}{c|}{$\mathbf{2 5}^{\text {th }}$ July } \\
\hline & $\begin{array}{c}\text { CSR- } \\
\mathbf{3 0}\end{array}$ & $\begin{array}{c}\text { PB- } \\
\mathbf{1 1 2 1}\end{array}$ & $\begin{array}{c}\text { PB- } \\
\mathbf{1 5 0 9}\end{array}$ & $\begin{array}{c}\text { HB- } \\
\mathbf{2}\end{array}$ & $\begin{array}{c}\text { CSR- } \\
\mathbf{3 0}\end{array}$ & $\begin{array}{c}\text { PB- } \\
\mathbf{1 1 2 1}\end{array}$ & $\begin{array}{c}\text { PB- } \\
\mathbf{1 5 0 9}\end{array}$ & $\begin{array}{c}\text { HB- } \\
\mathbf{2}\end{array}$ & $\begin{array}{c}\text { CSR- } \\
\mathbf{3 0}\end{array}$ & $\begin{array}{c}\text { PB- } \\
\mathbf{1 1 2 1}\end{array}$ & $\begin{array}{c}\text { PB-- } \\
\mathbf{1 5 0 9}\end{array}$ & $\begin{array}{c}\text { HB- } \\
\mathbf{2}\end{array}$ \\
\hline 30 DAT & 0.29 & 0.25 & 0.27 & 0.26 & 0.27 & 0.23 & 0.25 & 0.24 & 0.27 & 0.23 & 0.25 & 0.24 \\
\hline 50 DAT & 0.93 & 0.65 & 0.76 & 0.65 & 0.89 & 0.62 & 0.73 & 0.62 & 0.62 & 0.43 & 0.50 & 0.43 \\
\hline 70 DAT & 2.27 & 1.74 & 2.50 & 1.79 & 2.02 & 1.55 & 2.22 & 1.59 & 1.82 & 1.40 & 2.01 & 1.43 \\
\hline 90 DAT & 2.37 & 1.86 & 1.91 & 1.91 & 2.34 & 1.84 & 1.89 & 1.89 & 2.30 & 1.81 & 1.86 & 1.86 \\
\hline At Harvest & 1.82 & 1.84 & 0.42 & 1.90 & 1.73 & 1.75 & 0.40 & 1.81 & 1.42 & 1.43 & 0.33 & 1.48 \\
\hline
\end{tabular}

Table.7 Interactive effect of different dates of transplanting and varieties on grain yield $\left(\mathrm{kg} \mathrm{ha}^{-1}\right)$ of Basmati rice

\begin{tabular}{|c|c|c|c|c|c|}
\hline \multirow{2}{*}{ Treatments } & \multicolumn{5}{|c|}{ Varieties } \\
\hline & CSR-30 & PB-1121 & PB-1509 & HB-2 & Mean \\
\hline \multicolumn{6}{|c|}{ Transplanting dates } \\
\hline $25^{\text {th }}$ June & 3868.00 & 3890.50 & 3436.75 & 3969.25 & 3791.13 \\
\hline $10^{\text {th }}$ July & 3864.50 & 3802.00 & 3443.75 & 3929.50 & 3759.94 \\
\hline $25^{\text {th }}$ July & 2658.75 & 3526.50 & 3436.00 & 3807.50 & 3357.19 \\
\hline Mean & 3463.75 & 3739.67 & 3438.83 & 3902.08 & \\
\hline \multicolumn{6}{|c|}{ CD at 5\% (Transplanting dates) $=161.25 \quad$ CD at $5 \%_{\text {(Varieties) }}=151.52$} \\
\hline
\end{tabular}




\section{Helio Thermal Units (HTU)}

Heliothermal units (HTU) required to attain different phenophases of rice were calculated. It was observed that the crop transplanted on $25^{\text {th }}$ June availed higher heliothermal units and with delay in transplanting, HTU accumulation decreased. Highest heliothermal units were recorded in the crop transplanted on $25^{\text {th }}$ June followed by crops transplanted on $10^{\text {th }}$ July and $25^{\text {th }}$ July respectively. These findings match with those of Kaur and Dhaliwal, (2014) who reported that heliothermal units was maximum in crop transplanted on $15^{\text {th }}$ June as compared to on $30^{\text {th }}$ June and $15^{\text {th }}$ July transplanting. Among different transplanting dates, AHTU to reach physiological maturity ranged from 13659.93 to 17193.09 degree day hours, 13750.24 to 15596.42 degree day hours, 13750.24 to 15485.10 degree day hours and 12266.81 to 13582.11 degree day hours for varieties CSR 30, HB 2, PB 1121 and PB 1509, respectively (Table 3). The HTU accumulation was decreased with late transplanting for all the varieties during the crop season.

\section{Photo Thermal Units (PTU)}

The accumulated photothermal units (APTU) also showed the same trend as accumulated heliothermal units (AHTU) because both the indices are based on time period required for attaining physiological maturity. The PTU were higher in $25^{\text {th }}$ June transplanting followed by $10^{\text {th }}$ July, while the lowest PTU were recorded in the crop transplanted on $25^{\text {th }}$ July. At physiological maturity stage, higher PTU were recorded in variety CSR 30 followed by variety HB 2, PB 1121 and PB 1509 among all the transplanting dates and ranged from 21553.97 to 28998.35 degree day hours, 21675.97 to 26648.13 degree day hours, 21675.97 to 26474.20 degree day hours and 19137.05 to 23988.90 degree day hours for varieties CSR 30, HB 2, PB 1121and PB 1509, respectively (Table 4). Similar results were also obtained by Sandhu et al., (2013) reporting that accumulation of PTU decreased with the delay in date of transplanting.

\section{Heat Use Efficiency (HUE)}

Heat use efficiency was also computed at various growth intervals of rice crop and is presented in table 5. Heat use efficiency (HUE), is the conversion of heat energy into dry matter and depends on crop type, genetic factors and sowing time (Rao et al., 1999). Total heat energy available to any crop is never completely converted to dry matter even under most favourable agro climatic conditions. Among the dates of transplanting, $25^{\text {th }}$ June transplanted crop exhibited maximum HUE followed by $10^{\text {th }}$ July and $25^{\text {th }}$ July transplanting during the crop season. HUE decreased with delay in transplanting. Among different transplanting dates highest HUE at the time of harvest was recorded in variety HB 2 ranging from 0.77 to $0.86 \mathrm{~g} \mathrm{ha}^{-1}$ ${ }^{\circ} \mathrm{C}^{-1}$ day $^{-1}$, followed by variety PB $1121(0.71$ to $0.79 \mathrm{~g} \mathrm{ha}^{-1}{ }^{\circ} \mathrm{C}^{-1}$ day $^{-1}$ ), CSR 30 (0.68 to $\left.0.76 \mathrm{~g} \mathrm{ha}^{-1}{ }^{\circ} \mathrm{C}^{-1} \mathrm{day}^{-1}\right)$ and PB 1509 (0.30 to $0.34 \mathrm{~g} \mathrm{ha}^{-1}{ }^{\circ} \mathrm{C}^{-1}$ day $^{-1}$ ) respectively, during the crop season.

\section{Radiation use efficiency (RUE)}

The most important aspect of crop development affecting the dry matter production and economic yield is concerned with the development of leaf canopy and its effect on the efficiency of radiation interception. Radiation use efficiency values of rice crop are shown in table 6, computed at different growth intervals of rice crop. Amongst the dates of transplanting, $25^{\text {th }}$ June transplanted crop exhibited maximum RUE followed by $10^{\text {th }}$ July and $25^{\text {th }}$ July transplanting during the crop growth period. RUE decreased with delay in transplanting. The variation in RUE arose because of differential dry matter production in various treatments while intercepting different 
amount of radiation because of variation in canopy structure and LAI. It depend mainly on three factors, viz., architecture of the canopy intercepting the radiation, photosynthetic efficiency of the leaves in utilizing the intercepted radiation used in production of dry matter and loss of dry matter due to physiological process like respiration. At different transplanting dates highest RUE, during the time of harvest, was recorded in variety $\mathrm{HB} 2$ ranging from 1.48 to $1.90 \mathrm{~g} \mathrm{MJ}^{-1}$, followed by variety PB 1121 (1.43 to $1.84 \mathrm{~g} \mathrm{MJ}^{-1}$ ), CSR 30 (1.42 to $1.82 \mathrm{~g}$ $\mathrm{MJ}^{-1}$ ) and PB 1509 (0.33 to $0.42 \mathrm{~g} \mathrm{MJ}^{-1}$ ) respectively, during the crop season.

\section{Grain yield, $\mathrm{kg} \mathrm{ha}^{-1}$}

The response of rice cultivars to transplanting date is important when selecting the most appropriate cultivar for a particular transplanting date. Significant interactions were found on the effect of yield between dates of transplanting and varieties. The perusal of data in table 7 indicated that with each delay in transplanting of rice, there was significant decrease in grain yield of rice. Interaction between different dates of transplanting and different varieties showed that highest yield $\left(3969.25 \mathrm{~kg} \mathrm{ha}^{-1}\right)$ was produced with the combination of $25^{\text {th }}$ June transplanting in variety HB-2 in comparison to the lowest yield production $(2658.75 \mathrm{~kg}$ ha ${ }^{1}$ ) in $25^{\text {th }}$ July transplanting with variety CSR30. Among the varieties, the average grain yield of variety HB 2 was maximum $(3902 \mathrm{~kg}$ $\mathrm{ha}^{-1}$ ) followed by PB $1121\left(3740 \mathrm{~kg} \mathrm{ha}^{-1}\right)$, CSR 30 (3464 kg ha $\left.{ }^{-1}\right)$ and PB $1509(3439 \mathrm{~kg}$ $\left.\mathrm{ha}^{-1}\right)$. Oteng et al., (2013) reported that planting date can have a dramatic effect on crop development and yield. These findings were also supported by Soomro et al., (2001) and Sharma et al., (2011) who observed significant reduction in yield and yield contributing characteristics with delay in transplanting.
In conclusion, the different agro meteorological indices viz. GDD, HTU, PTU, HUE and RUE were higher in the basmati rice crop transplanted on $25^{\text {th }}$ June as compared to $10^{\text {th }}$ July and $25^{\text {th }}$ July. The present study indicates that the application of agro meteorological indices provides a scientific basis for determining the effect of temperature, radiation or photoperiod on phenological behaviour of a standing crop. These provide very clear picture of the amount, pattern and efficiency of heat energy consumption at different growth intervals and phenological stages of the crops. These can also be used very effectively for forecasting the occurrence of different phenophases of the crop.

\section{References}

Bishnoi, O.P., Singh, S. and Niwas, R. 1995. Effect of temperature on phonological development of wheat (Triticumaestivum L.) crop in different row orientations, Indian J. Agric. Sci., 65: 211-14.

Dalton, L.G. 1967. A positive response of yield on maturity of Sorghum. Crop Sci., 7: 721-26.

Dwyer, L.M. and Stewart, D.W. 1986. Leaf area development in field grown maize. $J$. Agron., 78: 334-48.

Economic Survey of India. 2015/16

FAOSTAT. 2014. FAO Statistical databases, http://www.fao.org, Food and Agriculture Organization (FAO) of the United Nations, Rome.

Ghadekar, S.R. 2001. Crop Climatology, Meteorology (Ed. S.R. Ghadekar. Agromet Publishers Nagpur: 186-19.

Gouri, V., Reddy, D.R., Rao, S.B.S.N. and Rao, A.Y. 2005. Thermal requirement of rabi groundnut in southern Telangana zone of Andhra Pradesh. J. Agrometeorol., 7(1): 90-94.

Ji, B., Sun, Y., Yang, S. and Wan, J. 2007. Artificial neutral networks for rice yield prediction in mountainous regions, $J$. Agric Sci., 145(3): 249-61. 
Kaur, A. and Dhaliwal, L.K. 2014. Agroclimatic indices of rice (Oryza sativa L.) under different dates of planting. Progressive Res., 9(1): 222-227.

Ketring, D.L. and Wheless, T.G. 1989. Thermal requirement for phenological development of peanut, J. Agron., 8(16): 910-17.

Majos, N.V. and Pava, H.M. 1980. Influence of ages of seedlings at transplanting on the performance of two low land rice varieties. J. Agric Food \& Nutrition., 2(2): 97-104.

Nuttonson, M.Y. 1995. Wheat climate relationship and use phenology in ascertaining the thermal and photothermal requirement of wheat. American Institute of Crop Ecology, Washington DC, pp. 338.

Oteng, D.P., Kyei, B.N. and Ofori, E. 2013. Yield of rice as affected by transplanting dates and plant spacing under climate change simulations. Wudpecker J. Agril. Res., 2: 55-63.

Rai, H.K. and Kushwaha, H.S. 2005. Performance of upland rice (Oryza sativa) under different transplanting dates and soil water regimes in tarai conditions. Indian J. Agric. Sci., 75: 817- 19.

Rajput, R.P., Deshmukh, M.R. and Paradkar, V.K. 1987. Accumulated heat unit and phenology relationships in wheat (TriticumaestivumL.) as influenced by planting dates under late sown conditions. J. Agric. Crop Sci., 159: 345-48.
Rao, V.U.M., Singh, D. and Singh, R. 1999. Heat use efficiency of winter crops in Haryana. J. Agrometeorol., 1(2): 143-8.

Sandhu, S.S., Kaur, P. and Gill, K.K. 2013. Weather based agro-indicies and grain yield of rice cultivars transplanted on different dates in Punjab. Internat. J. Agri. Food Sci. Tech., 10: 1019-26.

Satake, T. and Yoshida, S. 1978. High temperature induced sterility in Indicarices at flowering, Japanese $J$. Crop Sci., 47: 6-17.

Sharma, A., Dhaliwal, L.K., Sandhu, S.K. and Singh, S.P. 2011. Effect of plant spacing and transplanting time on phenology, tiller production and yield of rice (Oryza sativa L. Int. J. Agric. Sci., 7(2): 249-253.

Singh, S. and Pal, M. 2003. Growth, yield and phonological response of wheat cultivars to delayed sowing. Indian J. Pl. Physiol., 8: 277-86.

Soomro, H., Soomro, A., Oad, F. C., Ansari, A. H. and Oad, L. 2001. Effect of transplanting dates on yield and its related traits in Rice (Oryza sativa L. J. Bio. Sci., 1(5): 363-64.

Walia, U.S. and Walia, M.K. 2007. Scope of direct seeded rice in India. Proc. Biennial Conference, ISWS on New and Emerging Issues in Weed Science.2-3 November 2007, HAU, Hissar, India.,pp: 20.

Wang, J.Y. 1960. A critique of the heat units approach to plant response studies. Ecol., 41: 785-90.

\section{How to cite this article:}

Abhilash, Chander Shekhar Dagar, Raj Singh, Premdeep and Raman Sharma. 2017. Agrometeorological Indices and Phenology of Basmati Rice (Oryza sativa L.) under Different Dates of Transplanting. Int.J.Curr.Microbiol.App.Sci. 6(3): 212-222.

doi: https://doi.org/10.20546/ijcmas.2017.603.022 